\title{
A UNIQUE ARTISTIC INTERPRETATION OF THE ETHNOCULTURAL VALUES OF THE TURKIC PEOPLES
}

\section{Manzura Otajanova}

Senior Researcher, Institute Of Uzbek Language, Literature And Folklore of The Academy Of Sciences Of The Republic Of Uzbekistan

\section{ABSTRACT}

The article analyzes the fact that in the stories of Nodir Normatov, a writer with a unique style of prose, the use of poetic interpretations of ancient images belonging to the most ancient layers of Uzbek mythology to symbolic metaphors, myths and legends served to illuminate the spiritual world.

KEYWORDS:- Folklore, written literature, mythology, remifologization, mythologism, mythological plot, motif, artistic image, epic diffusion, mythological archetype, cosmogonic myth, animistic myth, zoonymic myth, rock cult, compositional structure.

\section{INTRODUCTION}

It is known that if modern Uzbek stories are analyzed from a mythopoetic point of view, the re-perception of mythological ideas in the literary text of works created by writers on the basis of the diffusion of mythical plots, motives and images; modeling of mythologems in the artistic interpretation of the mythological chronotope and mythological consciousness (i.e., the representation of the described reality through mythological archetypes); philosophical (the immortality of life in existence, the constant struggle of "being" and "absence"), structural (the composition of the work of art is based on a system of mythological images and various variants of motives) and poetic (the specific nature of the narrative style is based on mythology). discarded. In particular, various aspects of rural life, while seemingly simple at first glance, created a unique image of the wise way of life, national customs, historical beliefs and traditions that go back thousands of years. In the stories of the writer Nodir Normatov we find interpretations of ancient images belonging to the most ancient layer of Uzbek mythology, which have become poetic symbols. After all, in all genres of modern Uzbek prose there are different poetic interpretations of mythology. Among them, the predominance of the method of expressing artistic intention through the use of ancient mythical images as a symbol of archetypal details that are firmly entrenched in artistic thought.

When it comes to the essence of the works of the writer Nodir Normatov, it is expedient to use the term "rural prose" in relation to his work, which is formed as a specific direction in world, including Russian literature. "Rural prose" means 
CURRENT RESEARCH JOURNAL OF PEDAGOGICS 2(6): 108-115, June

2021 DOI: https://doi.org/10.37547/pedagogics-crjp-02-06-21

ISSN 2767-3278

(C)2021 Master Journals

\section{Crossref do) 81 Google}

Accepted 23 th June, 2021 \& Published 28 $8^{\text {th }}$ June, 2021

works of art that depict the unique way of life of people living in remote villages and the values that form the basis of national ethnoculture. V.Rasputin, who brilliantly described the life of the villages of Eastern Siberia, V.Lichutin, who created unique interpretations of literary ethnography based on the ancient traditions of the Primors; the works of V. Shukshin, who revived the ordinary life of the people of the Altai Krai in his stories and screenplays, are recognized as invaluable examples of twentiethcentury Russian rural prose.

\section{THE MAIN FINDINGS AND RESULTS}

In literary criticism, the peculiarities of "rural prose", the history of its emergence as a literary phenomenon and the mastery of writers working in this direction have been studied to some extent by scholars such as K. Parte, M. Razuvalova [1, pp. 204, 616]. In particular, S.Y. Koroleva's dissertation explores the ethnocultural nature of mythologies in this type of art, the genesis of mythological images, motifs and plots in prose works about the village in Russian literature [2, p. 26]. In her work on the analysis of prosaic works depicting the life of peasants in 21st century Russian literature, I.N.Ivanova is a "reloading" of mythopoetic archetypes, although she maintains the main problems, images, conflict nature and plot types of the last century in a certain transformational form; that is, it is characterized by the fact that it is a peculiar mirror of the resurrection [3, pp. 88-94].

The beautiful nature of Boysun district, which is an ancient ethno-cultural area of Surkhandarya oasis, is a unique artistic landscape of the experiences, thoughts, relationships, beliefs of plants and animals, legends and myths, customs and rituals that have been remembered for centuries. Nodir Normatov's stories contain unique interpretations of the mythological image, mythological archetype and mythopoetic context. We will try to shed light on the artistic role of the mythological image and archetypal symbols in the work in revealing the heroic character of the author by analyzing the story of the author "Koktoshlar" below.

The story of "Koktoshlar" arose when the writer remembered his memories of the death of his mother. The symbolism of the "blue stone", which runs from beginning to end, is a symbolic means of connecting generations with ancestral values, and a reinterpretation of ancient stonerelated notions in the writer's subconscious. According to the tradition of the Poshkhortsoys, if a person dies, he is buried in the grave, and the next day the closest relatives go to the grave in the morning. According to this custom, when they go to the grave, the sister of the deceased, Qurbonsara momo, popularly known as Apalar khola, takes the protagonist of the story, Kurban, together with her brothers Roziboy to the stream near the grave: "Take the blue stones here and take them to your mother's grave, these stones will be a sign, and years later you will find your mother's grave because of the stone you brought", he said [4, p. 338].

The "blue stone" detail used in the story is an archetypal symbol of the ancient Turks' cult of the rock cult, their animistic views based on vivid imagery of nature, and their belief in the symbolism of colors.

It is known that peoples living in different parts of the world had a custom of deifying mountain stones, especially blue stones, as sacred. In particular, in the Slavs, the blue stone was conceived as a mythological symbol representing the eternity of celestial existence [5, p. 207-240]. In the ancient Turks, the worship of the stone cult took on a special tradition [6, pp. 34-41, 602$609,6-19]$. In the imagination of our ancestors, blue stones were considered to be associated with the higher universe, the sky. Beliefs about the Blue God were formed as a result of the fact 
CURRENT RESEARCH JOURNAL OF PEDAGOGICS 2(6): 108-115, June

2021 DOI: https://doi.org/10.37547/pedagogics-crjp-02-06-21

ISSN 2767-3278

(C)2021 Master Journals

\section{Crossref do) 81 Google}

Accepted 23 th June, 2021 \& Published 28 $8^{\text {th }}$ June, 2021

that the sky was blue and the upper universe, which was thought to be the abode of spirits and gods, was represented by this color symbol. Therefore, in the mythology of the Turkic peoples, the above world, where the spirits of the dead are located, is associated with the color blue. The tradition of wearing blue as a sign of mourning in Uzbek mourning ceremonies, placing blue stones on graves, as well as cursing expressions such as "ko"kchangi kiyay" and "ko"kingni kiyay" as a direct wish for death are also influenced by these mythical views.

According to the Internet, there are many cemeteries and shrines in our country, which are called Koktash ota, Koktash buva. In particular, Koktash ota in Kyzyltepa district, Koktoshbobotepa near Samarkand, Koktash buva in Tashkent region, Koktash ota in Chirakchi district, Koktash vali near Termez, Koktosh ota, Kokgumbaz ota in Sherabad district, Koktonli ota in Andijan region, Kokari ota in Tashkent, Kokari ota in Narpay district the presence of tomb names is noted. According to the folk tradition, most of these shrines and tombs contain blue stones, and it was believed that children suffering from whooping cough could be cured if they drank water poured on this blue stone. The use of the epithet "blue" in the names of these places is also related to the mythical views associated with the world of spirits, which is understood to be the representation of this color in the sky.

The historical foundations of the mythological views, customs and rituals of our people, including the symbolic nature of the color blue in mourning ceremonies, go back to ancient Turkic mythology. As the literary scholar N. Rakhmonov noted, "The ancient Turks worshiped the blue God. The Blue God is the Blue Sky, and according to the ancient Turks, the Turkic peoples are the children of the Blue God and the brown earth" [7, p. 35]. That is why in the mythology and folklore of the Turkic peoples there are legends about the sacred blue wolf, the notion of the blue stone associated with the spirits of heaven.

According to folklorist D. Uraeva, "blue is the color of water and sky. Water and heaven are the places where the spirits of the dead find refuge. That is why blue symbolizes mourning at mourning ceremonies and mourning ceremonies" [8, 156-157]. According to M. Ruzieva, who studied the symbolism of color in folk songs, "because water and sky are considered to be the abode of the spirits of the dead, the color blue, which determines their color, is also a symbol of mourning" [9, pp. 282286].

The placement of blue stones on the mother's grave in Nodir Normatov's story "Koktoshlar" is also an interpretation of the ancient beliefs associated with the cult of blue stone, which is included in the literary text as an archetypal symbol.

The blue stone placed on the tomb of the deceased should have been considered to symbolically serve as a kind of vehicle for the soul of the deceased to pass to the higher world Heaven. This mythical view is also reflected in the popular curse "Put a blue stone on your chest". Thinking about the origin of this phrase, F. Eshbaeva writes: "The essence of this curse is related to ancient animistic notions... The blue stone is a symbol of death and loss. From ancient times it was customary to place untreated natural blue stone on the tomb. According to the animistic imagination, the blue stone is something that calls death, carrying death with it. The curse, "Let a blue stone be placed on your chest", reflected the desire of the cursed to die as soon as possible. According to 74-year-old Tokhtajon Aya Jarkinbaeva, a resident of the fourth branch of the Kok Arol farmers' association in Boka district of Tashkent, a rich man had a wife named Melibuvish when they were young. She was so delicate that she looked 
CURRENT RESEARCH JOURNAL OF PEDAGOGICS 2(6): 108-115, June

2021 DOI: https://doi.org/10.37547/pedagogics-crjp-02-06-21

ISSN 2767-3278

(C)2021 Master Journals

\section{Crossref do) 81 Google}

Accepted 23 th June, 2021 \& Published 28 $8^{\text {th }}$ June, 2021

down on her neighbors with disdain, and the women next door always cursed her, "Put a blue stone on your chest". Melibuvish choli died, his fortune was scattered, and he himself became an old woman. When the time of the accident came, he could not give up his life for several weeks and tortured his children and relatives. Then his sons, on the advice of the old women next door, put an apple-blue stone on Melibuvish's chest, and he died easily" [10, p. 56].

There is another interpretation of the archetypal symbols associated with colors in the story "Blue Stones" - the mythology of the black snake. The hero remembers how he brought the blue stones from the tomb from the stream when he went to visit his mother's grave:

"As I stared at the rocks, I remembered the day I pulled him out of the stream below. My aunt and brothers were far ahead of me. As I picked up a rock that came like a handkerchief, I would often bend over and stop to rest. What happened was that in the meantime I sat down to rest in a shelter. Then I wanted to lie down and sleep for a while. When I opened my eyes, Gulistan momo was standing on top of me. "My giants said that a black snake was trying to snatch your blueberry. Look, I killed him", he said solemnly. I stared around in amazement, frightened. Next to me lay a crushed black snake. "Take your stone" said the old woman, "and remember to keep a record of it". She guards your mother's soul. This stone was once an angel of heaven who served the Blue God Father. He lay here until your mother died, and now he's on his way. This black snake was against his going". When he said that, he disappeared from my sight in an instant" [4, pp. 338-389].

There are several mythologies in the passage above, all of which are embedded in the poetic interpretation of the myth that explains the reason for the majesty of the blue stone. The transformation of the blue stone into an ordinary stone, which was once an angel of heaven who once served the Blue God, is an evolution in ancient mythology, that is, through the motive of transitioning from one form to another. The phenomenon of evolution in mythology is basically twofold in its nature and interpretation, and the transformation of one living thing into another, or the transformation of a particular thing into another thing, is considered a "partial evolution" or "incomplete evolution", the transformation of a living being into a definite thing-event, or the transformation of an object into a living thing, is called "complete" or "complete evolution" [11, p. 14].

The celestial being who served the blue god is an example of a complete evolution of the divine creation into a blue stone.

In ancient myths, the servants of the Blue God, who imagined the higher universe to be his abode, and the objects and beings around him were also interpreted with the blue sign; as well as the mythological function of the celestial being turned into a blue stone, that is, the task of guarding, is expressed in a new way in the story of Nodir Normatov. In other words, as Gulistan momo puts it, the hero's mother "is going to do her job, the blue stone that lay in the river until she died". This functional-semantic task assigned to the image of the Blue Stone also indicates that this mythopoetic detail belongs to the cult of the sky and the Blue God, which is the world of spirits.

Several archetypal images related to the dualistic mythology of our ancestors about the eternal struggle of good and evil were used in the artistic expression of this myth, narrated through the dream motif in the process of bringing the blueberry in the stream through the narratorhero's speech. One of them is the image of a "giant", although this mythical character, whose origin goes back to the Avesto, is often described in fairy tales, legends and epics as related to the 
CURRENT RESEARCH JOURNAL OF PEDAGOGICS 2(6): 108-115, June

2021 DOI: https://doi.org/10.37547/pedagogics-crjp-02-06-21

ISSN 2767-3278

(C)2021 Master Journals

\section{Crossref do) 81 Google}

Accepted 23 th June, 2021 \& Published 28 $8^{\text {th }}$ June, 2021

world of evil, sometimes there are also notions of bakhshis-neighbors who are engaged in the treatment of patients under the auspices of the giants. Usually, such people who subdued the giants were called "man with a giant", "devband", "devona". If such people do not perform the treatment with the help of giants, the giants will injure themselves. Such a phenomenon is described in the vernacular as "so-and-so was conquered by giants" [12, pp. 117-119].

Gulistan momo, described in the story "Koktoshlar", is one of such "giant" people. The woman, whose husband died in Siberia during the years of repression, has an only daughter, who is also married to one of the mountain villages, so she lives alone. That's why some people are scared of her. Fear him. When he comes home, give him some bread immediately".

Indeed, Gulistan momo had supernatural nature, her foreknowledge of certain events, and her statement that "my giants said", "my giants reported" (for example, that the narrator-hero came to the head of the grave, just as Boykul's son, the school principal Mamarayim, had a son.) caused people to be a little frightened of her. The protagonist of the play is sitting next to his mother's grave, imagining, "Welcome, my child. My giants told you to come", the voice forced him to turn. When he looked, he saw Gulistan momo behind him. Twenty years later, the protagonist is surprised that his face, stature, and stature have hardly changed, and that he was in a blackand-white, almond-colored brown-and-red shirt when he was rescued from that snake. As if reading the thoughts of the protagonist, the old woman said: "Yes, that song. It was your mother's spirit who told me to kill this black snake" [4, p. 339].

The black snake depicted in the story is a zoomorphic, i.e. mythological, image of evil that fights against the forces of good. Because in ancient Turkic mythology, black was often interpreted as a symbolic representation of the underworld, darkness, obscurity, evil forces. "In ancient times, white was considered the mythological equivalent of day, bright day, milk, wheat, water, sky, and black was considered the mythological equivalent of night, the underworld" [13, p. 112]. The Turkic peoples of Central Asia believe that if a person sees a black snake in a dream, it is an enemy; if he sees a white snake - wealth, happiness, luck; if a black snake came out of a man's path, he would suffer from his enemy, if a white snake came out - it was imagined that wealth would come $[14, \mathrm{pp}$. 811]. In Uzbek folk tales, the black snake is depicted as a symbol of evil power that harms the hero. For example, in the fairy tale "Bekmirza and Shavkatmirza" [15, p. 133], the protagonist sees a tiger suffocating in the clutches of a black strangled snake and kills it with a sword. While the tiger depicted in this fairy tale is a creature involved in the world of goodness, goodness, the black snake is the opposite - an expression of evil forces.

Since the blues in the stream are celestial bodies turned to stone, the attack of the black serpent on them can be regarded as a mythopoetic interpretation of the onslaught of evil forces seeking to destroy existence. The image of Gulistan momo, who crushed the black snake and allowed the blue in the hero's hand to fulfill its eternal function, is a symbol of the noble power that mediates between the world of people and the world of spirits and leads mankind to the great goal of preserving the world.

There is another mythology related to the detail of the snake in the story "Koktoshlar", which reflects the mythological views of our people about the "domestic snakes". The protagonist of the work describes a scene he saw when he went to see Gulistan's grandmother with Mamarayim aka, the school principal in the village of Poshkhort: 
CURRENT RESEARCH JOURNAL OF PEDAGOGICS 2(6): 108-115, June

2021 DOI: https://doi.org/10.37547/pedagogics-crjp-02-06-21

ISSN 2767-3278

(C)2021 Master Journals

\section{Crossref do) 81 Google}

Accepted 23 th June, 2021 \& Published 28 $8^{\text {th }}$ June, 2021

"The dark house was full of smoke, and the ceilings and walls were smashed, and something else was moving", he said. "Look, there's a house snake in the corner", whispered Mamarayim [4, p. 340].

At this point, the folk beliefs about the cult of the snake, which are called in our language, such as "white snake", "house snake", "cobra". In many parts of the country, when a white snake is seen in a house, it is considered a ghost and immediately sprinkled with flour or milk in a smaller container. It was believed that the snake would do no harm if it did so. Such snakes could not be killed or beaten because they were thought to be a noble animal that protected the household from various evils. The Khorezmians imagine that the white snake living in the house is the manifestation of Hizr in the form of an animal [16, p. 114-115]. The appearance of a snake in the corner of Gulistan's grandmother's house means that the owner of this house is protected by the sponsoring forces. Here, too, we see a dualistic myth, a mythopoetic interpretation of the archetypal motive of the eternal struggle between the forces of good that preserve the existence of the universe and the forces of evil that seek to destroy it. While the black snake trying to attack the narrator-hero, who is pulling the blue out of the stream, is a symbol of the power involved in evil, the white snake guarding Gulistan's grandmother's house is a symbol of good power.

Consequently, the mythology of the "black snake" is enriched with a new social content that embodies the realities of the period described in the play, while retaining its archetypal meaning in the writer's artistic interpretation. When the protagonist goes to visit her mother's grave, Gulistan's grandmother tells her: "Now listen to me. When the time comes, when I leave this world, you will take three blue stones from this stream to my grave. I have no one but my giants and demons. My daughter also fell ill and died.
He didn't listen to me. My mother turned her back on me because she was crazy" [4, p. 339]

It was a testament to the innocence of a woman who had been rejected by her relatives and condemned to loneliness because of her unusual lifestyle, and who had accompanied the jinn giants. The protagonist listens to her grandmother and promises to put blue stones in the grave, saying, "That's what you say". Shortly afterwards, one summer day, the heroine Gulistan, who was on vacation in her native village, remembers that will when she hears that her grandmother has died. But when he goes to take the ashes from the stream to bury his grandmother's grave, he realizes that he cannot fulfill his grandmother's last request when he learns that the land has been taken over by some wicked and conspiratorial man, who pays the people for the stone of the river as building material. The writer tells his story, "I will remember a black snake trying to bite me until I fulfill this will. He concluded by saying, "Even if the giants did not tell the old woman that a "big black snake" would take over in the future". In this way the writer seems to remind the reader once again of the age-old wisdom that the dualistic confrontation of the struggle between good and evil is one of the eternal truths of life.

\section{Conclusion}

To conclude, Nodir Normatov, the author of outstanding works in the field of "rural prose" in modern Uzbek literature, along with elements of ancient Turkic mythology, using various mythical views, mythical motives and beliefs of our people through mythopoetic stylization, the spiritual world of rural people was able to create a unique artistic interpretation of the system of style and ethno-cultural values. Although the mythology in the author's story "Koktash" is a unique expression of ancient archetypal images preserved in the memory and subconscious of 
CURRENT RESEARCH JOURNAL OF PEDAGOGICS 2(6): 108-115, June

2021 DOI: https://doi.org/10.37547/pedagogics-crjp-02-06-21

ISSN 2767-3278

(C)2021 Master Journals

Crossref dof 81 Google

Accepted 23th June, 2021 \& Published 28 $8^{\text {th }}$ June, 2021

the people, it is a re-perceived mythopoetic interpretation, enriched with a new functionalsemantic content.

\section{REFERENCES}

1. Parte K. (2004) Russian Village Prose: A Bright Past. - Tomsk: Publishing house of Vol. University. - p. 204; Razuvalova A. (2015) Village Writers: Literature and Conservative Ideology of the 1970s. Moscow: New literary review. - p. 616. (Партэ К. Русская деревенская проза: светлое прошлое. - Томск: Изд-во Том. ун-та, 2004. - 204 с.; Разувалова А. Писатели-«деревенщики»: литература и консервативная идеология 1970-х годов. - М.: Новое литературное обозрение, 2015. - 616 c.)

2. Koroleva S.Y. (2006) Artistic mythologism in prose about the village of the 1970s - 90s: AKD. - Perm. - p. 26. (Королева C.Ю.Художественный мифологизм в прозе о деревне 1970 - 90-х годов: АКД. Перм, 2006. - 26 с.)

3. Ivanova I.N. (2013) Village prose in contemporary Russian literature: the end of a myth or a reboot? Philological sciences. Questions of theory and practice. - Tambov: Diploma. - No 6 (24). - Part I. - pp. 88-94. (Иванова И.Н. Деревенская проза в современной отечественной литературе: конец мифа или перезагрузка? // Филологические науки. Вопросы теории и практики. - Тамбов: Грамота, 2013. - № 6 (24). - Ч.I. - C.88-94.)

4. [4] Nodir Normatov. (2012) Bisot. Stories and tales. - Tashkent: Sharq. - p. 338. (Нодир Норматов. Бисот. Қиссалар ва хикоялар. - Тошкент: Шарқ, 2012. Б.338.)

5. Ageeva R.A. (2019) Blue stones in the traditional culture of the Eastern Slavs. Balto-Slavic Studies - XX: Collection of Scientific works. - Moscow: - pp. 207-240. (Агеева Р.А.Синие камни в традиционной культуре восточных славян / Балтославянские исследования-ХХ: Сб. науч. трудов.- М., 2019. -С.207-240.)

6. Potapov L.P. (1946) Cult of mountains in Altai. Soviet ethnography. - Moscow: No 2. pp. 34-41; Tokarev S.A. (1990) About the cult of mountains and its place in the history of religion // Tokarev S.A. Early forms of religion. - Moscow: - pp. 602-609; Jumanazarov U. (1990) History, myth and religion. - Tashkent: Uzbekistan. - pp. 6-19. (Потапов Л.П Культ гор на Алтае // Советская этнография. - М., 1946. - №2. С.34-41; Токарев С.А. О культе гор и его месте в истории релегии // Токарев С.А. Ранние формы релегии. - М., 1990. С.602-609; Жуманазаров У. Тарих, афсона ва дин. - Тошкент: Ўзбекистон, 1990. Б.6-19.)

7. N.Rahmonov. (2006) Ancient Turkic-runic inscriptions of Uzbekistan. - Tashkent. "Fan". - p. 35. (Н.Рахмонов. Ўзбекистоннинг кўхна туркий -рун ёзувлари. Т., “Фан”,2006, 35-б.)

8. Uraeva D. (2005) Genre structure, genesis and art of Uzbek mourning folklore: Candidate of Philological Sciences. Diss. Tashkent: - pp. 156-157. (Ўраева Д. Ўзбек мотам маросими фольклорининг жанрий таркиби, генезиси ва бадиияти: Филол. фанлари номз. дисс. - Тошкент, 2005. Б.156-157.)

9. Ruzieva M. (2016) The arrival of blue as the epic hero, space and place names. Traditional Republican scientific-practical conference of young linguists and literary critics. - Tashkent: - pp. 282-286. (Рўзиева М. Кўк рангнинг эпик қахрамон, макон ва 
CURRENT RESEARCH JOURNAL OF PEDAGOGICS 2(6): 108-115, June

2021 DOI: https://doi.org/10.37547/pedagogics-crjp-02-06-21

ISSN 2767-3278

(C)2021 Master Journals

Crossref do: 81 Google

Accepted 23th June, 2021 \& Published 28 ${ }^{\text {th }}$ June, 2021

жой номлари сифатида келиши / Ёш тилшунослар ва адабиётшуносларининг анъанавий республика илмий-амалий анжумани. - Тошкент, 2016. Б.282-286.)

10. Eshboeva F.X. (2008) Genre features and art of Uzbek folk curses: Candidate of Philological Sciences. Diss. - Tashkent. - p. 56. (Эшбоева Ф.Х. Ўзбек халқ қарғишларининг жанр хусусиятлари ва бадиияти: Филол. фанлари номз. дисс. Тошкент, 2008. - Б.56.)

11. Gezalov F. (1990) The structure of Azerbaijani fairy tales. AKD. - Tashkent: - p. 14. (Гезалов Ф. Структура азербайджанских волшебных сказок. АКД. - Ташкент, 1990. - С.14.)

12. Taidzhanov K., Ismailov H. (1986) Features of pre-Islamic beliefs among the Uzbek Karamurts. Ancient beliefs and cults of the peoples of Central Asia Historical and ethnographic essays. - Moscow: - pp. 117119. (Тайджанов К., Исмаилов Х. Особенности доисламских верований у узбеков-карамуртов /Древние обряды верования и культы народов Средней Азии Историко-этнографические очерки. - М., 1986. - C.117-119.)

13. Ruzieva M. (2016) Color symbolism in Uzbek folklore. - Tashkent: Fan. - p. 112. (Рўзиева М. Ўзбек фольклорида ранг символикаси. - Тошкент: Фан, 2016. Б.112.)

14. Andreev M.S. (1923) Prophetic dreams, a few signs and the children's game "MagpieCrow" among some peoples, mainly Central Asia. Bulletin of the main Central Asian museum. Issue 2. - Tashkent: - pp. 8-11. (Андреев М.С. Вещие сны, несколько примет и детская игра "Сорока-Ворона" среди некоторых народов, главным образом Средней Азии // Известия главного среднеазиатского музея. Вып.2. - Т.: 1923. - C.8-11.)

15. Gulpari (Namangan fairy tales). Uzbek folk art. Collector T.Gaziboev. - Tashkent: Literature and Art Publishing House, 1969. p. 133. (Гулпари (Наманган эртаклари). Ўзбек халқ ижоди. Тўпловчи Т.Ғозибоев. - Тошкент: Адабиёт ва санъат нашриёти, 1969. - Б.133.)

16. Snesarev G.P. (1969) Relics of pre-Muslim beliefs and rituals among the Uzbeks of Khorezm. - Moscow: Nauka. - pp. 114-115. (Снесарев Г.П. Реликты домусульманских верований и обрядов у узбеков Хорезма. - М.: Наука, 1969. - С.114-115.) 